\title{
The Impact of Teacher Corrective Feedback on EFL Student Writers' Grammatical Improvement
}

\author{
Kanyakorn Sermsook ${ }^{1}$, Jiraporn Liamnimitr ${ }^{1} \&$ Rattaneekorn Pochakorn ${ }^{1}$ \\ ${ }^{1}$ Department of English for International Communication, Rajamangala University of Technology Srivijaya, \\ Nakhon Si Thammarat, Thailand \\ Correspondence: Kanyakorn Sermsook, Department of English for International Communication, Rajamangala \\ University of Technology Srivijaya, Nakhon Si Thammarat, 80110, Thailand. Tel: 66-819-597-387. E-mail: \\ psuratchawadee@yahoo.com
}

Received: July 26, 2017 Accepted: September 2, 2017 Online Published: September 5, 2017

doi: 10.5539/elt.v10n10p43 URL: http://doi.org/10.5539/elt.v10n10p43

\begin{abstract}
This paper aims to provide information about teacher corrective feedback that would be helpful for EFL students' writing improvement. It focuses on feedback provided to correct grammatical errors made by student writers as the author finds that this type of errors can obstruct the effectiveness of students' pieces of writing and may result in written miscommunication. Both direct and indirect teacher feedback types are discussed. Some pedagogical suggestions have been made based on the findings. It is hoped that this review article can help teachers and students in a writing class achieve the goal of producing grammatically correct English writing assignments.
\end{abstract}

Keywords: direct feedback, grammatical errors, indirect feedback, oral feedback, teacher corrective feedback, written feedback

\section{Introduction}

Writing in the English language has been considered a difficult skill for EFL students to master because this group of students rarely has a chance to write in English (Kim \& Kim, 2005; Kongsuebchart \& Suppasetseree, 2015; Sermsook et al., 2017). Consequently, producing an error-free piece of English writing is a challenging task for them. A great number of studies in the field of second language acquisition (SLA) and Error Analysis (EA) reveal that EFL students' written work contains various types of errors (Huang, 2006; Rattanadilok Na Phuket \& Othman, 2015; Sermsook et al., 2017; Zafar, 2016; Zheng \& Park, 2013). Among those errors, grammatical ones can pose serious difficulties for EFL students since the grammatical rules of English and those of their native language are relatively different (Nonkukhetkong, 2013). These grammatical errors reduce the effectiveness of students' written assignments and may result in written miscommunication. Some examples of grammatically incorrect English sentences written by EFL students are as follows:

- My mother brought the level to the temple. (My mother brought the food container to the temple.)

- You stick an F.

(You have got an F.)

- Paula is a lady pretty.

(Paula is a pretty lady.)

- She name is Mook.

(Her name is Mook.)

- I am pass an exam.

(I pass an exam.)

The above sentences illustrate the communication failure which was mainly caused by grammatical errors. In order to assist these EFL student writers, scholars and researchers in the field of second language acquisition have searched for approaches which contribute to the students' writing improvement, including the accuracy in grammar use. And giving feedback is one of the fundamental approaches that have been accepted and extensively studied, especially feedback given by writing teachers. Although Truscott (1996) points out that giving corrective feedback can be harmful since it can damage students' language learning process, the findings from the past studies argue for its necessity.

For decades, a considerable number of studies have been conducted to determine whether teacher corrective feedback is effective. Most of the studies provided evidence of the usefulness of teacher corrective feedback 
(Bitchener, 2008; Bitchener et al., 2005; Ellis et al., 2006; Ferris \& Robert, 2001; Hosseiny, 2014; Ismail et al., 2008; Ohta, 2001; Sarvestani \& Pishkar, 2015; Tootkaboni \& Khatib, 2014). Despite this convincing evidence, debates about which type of teacher feedback is the most effective for students' writing improvement remain ongoing. A good deal of research has been later carried out to bring a resolution to this controversial issue. Based on the previous findings, two types of teacher corrective feedback are widely discussed. They are direct feedback and indirect one. Both feedback types can be in the written and verbal forms. Previous studies (Ferris \& Robert, 2001; Hosseiny, 2014; Sarvestani \& Pishkar, 2015; Tootkaboni \& Khatib, 2014) have indicated that both types of teacher feedback benefit student writers' writing development.

Realizing the effectiveness of teacher feedback, the author as a writing teacher who has vast experience with EFL students making various types of grammatical errors is intrigued by this approach. This literature review of previous studies, therefore, intends to provide useful information about teacher corrective feedback. The present review article focuses on direct and indirect teacher feedback, either in the written or verbal forms, which is proved to be effective in reducing grammatical errors in EFL or ESL student writers' pieces of writing.

It is hoped that this review article will be helpful for writing teachers who are searching for a method to help their students, in particular EFL students to develop their English writing skills. Additionally, this article may help raise students' awareness of the teacher's good intention, so they gain more understanding about their teacher's feedback. This may lead to students' optimal utilization of the feedback given by their teacher.

\section{Teacher Corrective Feedback}

In writing classes, corrective feedback is defined as a teacher's indication given to students in order to let them know that their written work contains errors (Lightbown \& Spada, 1999). There are many different terms in calling this technique, such as corrective feedback, error correction, and negative evidence (Karim \& Nassaji, 2013). It doesn't matter which term is used since they share the same objective which is to inform students that errors do exist in their written work, and it needs a correction.

The better-known teacher corrective feedback is teacher written feedback. This type of feedback is provided by a teacher by means of writing their comments, correction of errors, etc. on students' pieces of writing. As the focus of the present review article is grammatical correction, the feedback concerning grammar improvement is reviewed and discussed. Teacher corrective feedback that involves grammar correction is form-focused feedback (Farrokhi \& Sattarpour, 2011; Ismail et al., 2008; Razali \& Jupri, 2014; Sheen et al., 2009). According to past studies, this type of feedback can be divided into two groups: focused and unfocused. The first one refers to the correction of the targeted grammatical errors frequently made by most of the students, and the teacher finds that they may become serious without any correction. The latter one concerns global errors when teachers correct all grammatical errors found in students' written work. Scholars (Eslami, 2014; Farrokhi \& Sattarpour, 2011; Ismail et al., 2008; Sheen et al., 2009) state that focused feedback type is more effective because students can focus on one small error at a time which can eventually help them avoid making that error in the future. A great number of studies reported the effectiveness of teacher written feedback. Among those studies, Ellis et al. (2006) indicate that written feedback helps improve students' use of past tense with -ed ending. Bitchener (2008) also states that written corrective feedback benefits EFL writers' writing performance in both short and long term. Later, Sarvestani and Pishkar (2015) point out that written feedback type assists students to accurately use English articles.

Another type of teacher written feedback proposed by Hyland and Hyland (2001) is in the forms of praise, criticism and suggestions. According to them, all of these three forms can be used together to make teacher written feedback the most effective. Sincere praise is normally used to soften criticism and suggestions. Praise can also enhance students' motivation and a good relationship between teachers and students in a writing class. In the study of Razali and Jupri (2014), these three forms of written feedback, when being used appropriately, can result in a satisfying improvement in students' written assignments.

Apart from teacher feedback in the written form, teacher oral feedback also plays an important role in students' writing improvement. This type of feedback can be done to a whole class to discuss errors made by most of the students. It can also be done personally between a teacher and one student in a one-to-one conference. Previous studies (Cepni, 2016; William, 2003) indicate that oral feedback makes corrective feedback given by a teacher more effective because it gives an opportunity to both teachers and students to clarify their doubts. Erlam et al (2013) assert that oral corrective feedback can help promote students' self-correction of past tense verb forms and articles. According to Sobhani and Tayebipous (2015), oral feedback significantly reduces students' grammatical errors. And to be most beneficial, they state that it should be combined with the written one. Similarly, after an experiment, Cepni (2016) found the usefulness of oral corrective feedback in that it helped her 
students correctly use past tense and English articles. In addition, Hamidun et al (2012) mention that oral praise can be given to students to boost up their confidence in writing.

In summary, teacher corrective feedback can be given either directly or indirectly, and it can be written or oral. In most research studies, oral feedback is normally employed along with the written one to assure that students understand what teachers would like to communicate to them. As pointed out by Bitchener et al. (2005), exposing students to both oral and written corrective feedback can yield the most effective results.

\subsection{Review of Direct Corrective Feedback and Its Advantages over EFL Students'Grammatical Accurate Use}

Direct feedback provided on students' written work has been defined by several scholars. Ferris and Robert (2001) define it as the correction made by a teacher. Likewise, Ellis (2009) states that it is the way to inform students about the location and the correct forms of the errors. Another group of scholars, Bitchener et al. (2005) indicate that direct feedback is the identification and the correction of errors provided by teachers to students. Direct corrective feedback receives great attention and has been studied extensively in order to determine if it is helpful for students' writing improvement. Following are some research studies contributing to the effectiveness of direct feedback type.

Bitchener et al. (2005) carried out a sudy to compare the effects of three types of teacher feedback: 1. Direct, explicit written feedback and 5-minute conference 2. Direct, explicit written feedback and 3. No corrective feedback on students' improvement in the use of prepositions, simple past tense and articles. Their findings showed that the first type of feedback which comprised direct written feedback and oral feedback was the best technique for improving students' use of past tense and articles.

Sheen (2007) later concluded that direct corrective feedback was effective in assisting students to correctly use English articles. Moreover, it helped promote the students' analytic skill in using the language.

In similar, Hamidun et al. (2012) confirmed that direct corrective feedback could result in better writing performance of students, especially the ones with low language proficiency. Moreover, this study further concluded that it also boosted up students' positive attitude toward writing. Likewise, Farrokhi and Sattarpour (2012) reported the positive effects of direct feedback on students' accurate use of English articles.

Based on the review study of Srichanyachon (2012), it can be summarized that direct feedback is useful for beginner students because they can immediately make use of the correct forms given by the teacher. She also points out that with teachers' clear explanation of the accurate use of the target grammatical features, direct feedback may help foster students' long-term language acquisition. Moreover, it can enhance EFL students' learning motivation since they are assisted by the teacher who may be the only reliable source for them in a writing class. She further asserts that to avoid any disadvantages that can be caused by using direct teacher feedback, careful ways of giving feedback must be seriously considered.

Perez et al (2013) found the students' improvement in grammar use in the revision of their writing after they received direct feedback from their teacher. Later, Hosseiny (2014) concluded that direct feedback was more advantageous than indirect one in case of complex errors, such as sentence structure and word choices. She also indicates that teachers should make sure students understand the corrective feedback given by them for the most effectiveness.

Sarvestani and Pishker (2015) state that direct corrective feedback helps improve students' grammar knowledge of English articles after an eight-week experiment. They also mention that oral face-to-face feedback helps create students' better understanding of the targeted grammatical features. They conclude that this could reinforce long-term memory of those features.

Not long after that, Almasi and Tabrizi (2016) conducted a study to compare the effectiveness of direct and indirect teacher feedback. Their findings also indicated that EFL Iranian students receiving direct feedback type outperformed the other two groups who received indirect feedback and no feedback in using prepositions, articles and past tense verb forms.

To conclude, direct corrective feedback which is also known as explicit feedback is the strategy that should be employed to assist lower proficiency or beginner EFL students to overcome the difficulties of uncomplicated grammatical rules in their writing, for instance, articles and prepositions. It is also suggested to apply such feedback to clarify untreatable grammatical points, such as sentence structure, word choices, etc. Though this type of feedback is advantageous, it has to be carefully implemented in writing classes. Without teachers' thoughtful use, it may be a harmful tool which can discourage students' language learning. 


\subsection{Review of Indirect Corrective Feedback and Its Advantages over Grammar Knowledge of EFL Student Writers}

The definition of indirect corrective feedback is various. Lightbown and Spada (1999) define it as the situation in which a teacher indicates the error location, but leave students to self-edit the errors. Likewise, Ferris \& Robert (2001) state that indirect corrective feedback is the indication made by a teacher by underlying the errors or giving the codes for the errors. Another definition given by Bitchener et al. (2005) is teachers' identification of errors without any corrections with the intention that students should correct the errors by themselves. Ellis (2009) mentions that indirect feedback is used when teachers only signal the location of errors. All in all, the purpose of indirect corrective feedback is just to indicate the location of errors without any information of the correct forms. Students have to self-correct the errors they have made. Researchers believe that this type of feedback can help foster students' long-term language acquisition. Its advantages can be viewed through the findings from the following studies.

Hyland and Hyland (2001) indicate that indirectness of teacher feedback can lead to incomprehension and miscommunication between teachers and students; therefore, they suggest that it is more effective to use this feedback type with high language proficiency students.

Based on the study of Ferris and Robert (2001), it was found that indirect feedback assisted students to do self-correction of the treatable grammatical errors, such as verbs, noun endings and articles. However, it failed to help them self-correct untreatable ones like sentence construction and word choices. In the late 2000s, Noroozizadeh (2009) concluded that through indirect feedback, his advanced level students could self-remove focused grammatical errors from their final draft of writing.

This is in line with the conclusion made by Erlam et al. (2013) which indicates that indirect feedback enables students to self-repair their grammatical errors. Eslami (2014) also lends support to the effectiveness of indirect feedback after proving that it is more useful to help low-intermediate EFL students self-correct simple past tense errors. He also adds that this type of feedback with focused errors promotes students' correct linguistic form acquisition in the long run.

Additionally, Jamalinesari et al. (2015) assert that the EFL students who received indirect feedback outperformed the direct feedback group in certain categories of grammatical errors. It also promoted the encouraging environment for writing learning.

Westmacott (2017) also reports the advantages of teacher indirect feedback in grammar improvement. The study showed stronger positive effects of indirect feedback in comparison to the direct one as it enhances students' learning autonomy.

In short, indirect corrective feedback is another recognized feedback type. Based on the literature review, it should be used with students who possess a relatively good command of the target language. Furthermore, it should be utilized to correct the treatable errors, such as nouns, verb forms, etc., and those errors should be focused. Most importantly, understandable and consistent methods of giving indirect feedback have to be implemented to make sure that students are able to use the feedback for their self-correction.

\section{Pedagogical Implications}

Some pedagogical implications can be made based on this literature review.

First, regardless of oral or written styles, both teacher direct and indirect corrective feedback approaches are beneficial to student writers' grammatical improvement. Importantly, some factors, such as types of students, students' language proficiency level and types of errors have to be taken into account when feedback is given.

Second, direct corrective feedback can be a helpful and easily employed method to improve low proficiency students' writing skill in a limited time. Nevertheless, it must be noted that when direct corrective feedback is used, teachers' careful thought and thoughtful ways of giving feedback are necessary. This type of feedback, if being used alone, can lead to misunderstanding and can result in students' motivation loss in language learning. Therefore, oral feedback is suggested to be included for clear and precise explanation.

Next, for teacher indirect feedback, when symbols or codes are used, teachers have to make sure that students know the meaning of these symbols and how to apply them for the improvement of their grammatical errors. William (2003) states that consistent symbols or codes must be used to signal errors, and teachers should train students to use these codes or symbols.

Additionally, no matter which type of feedback is provided, it is suggested that focused feedback type be used because it helps students stay focused on a few errors at a time. It may also indirectly create students' positive 
attitude toward language learning.

Last but not least, praise can be used together with teacher corrective feedback, criticism and suggestions in order to encourage EFL students' confidence and motivation. Although errors are made, through teachers' praise, students believe that they can improve.

\section{Conclusion}

Based on the previous literature, it can be concluded that both teacher direct and indirect feedback, either in the written or oral forms are beneficial to the correction of EFL student writers' grammatical errors. Which type of feedback is the most effective depends on various factors, so it remains the responsibility of writing teachers to figure out. This review article, to some extent, may help provide the possible guidelines.

In addition to teacher feedback, another important factor that cannot be overlooked is a good relationship between teachers and students. Clear, precise and encouraging teacher feedback can absolutely contribute to EFL students' writing improvement. With effective techniques and understanding between teachers and students, it is not far from reach for students to produce a good piece of writing.

\section{Acknowledgments}

The authors would like to thank Rajamangala University of Technology Srivijaya for being the main supporter in writing this article. Grateful thanks also go to the reviewers of the early draft of this article.

\section{References}

Almasi, E., \& Tabrizi, A. R. N. (2016). The effects of direct vs. indirect corrective feedback on Iranian EFL learners' writing accuracy. Journal of Applied Linguistics and Language Research, 3(1), 74-85.

Bitchener, J. (2008). Evidence in support of written corrective feedback. Journal of Second Language Writing, 17, 102-118. https://doi.org/10.1016/j.jslw.2007.11.004

Bitchener, J., Young, S., \& Cameron, D. (2005). The effect of different types of corrective feedback on ESL student writng. Journal of Second Language Writing, 14, 191-205. https://doi.org/10.1016/j.jslw.2005.08.001

Cepni, S. B. (2016). A replication study: Oral corrective feedback on L2 writing; two approaches compared. Procedia Social and Behavioral Sciences, 232, 520-528.https://doi.org/10.1016/j.sbspro.2016.10.072

Ellis, R. (2009). A typology of written corrective feedback types. ELT Journal, 63(2), 97-107. https://doi.org/10.1093/elt/ccn023

Ellis, R., Loewen, S., \& Erlam, R. (2006). Implicit and explicit corrective feedback and the acquisition of L2

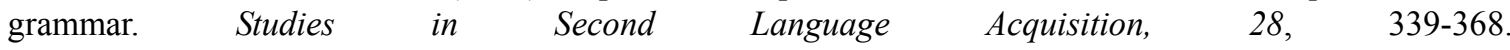
https://doi.org/10.1017/s0272263106060141

Erlam, R., Ellis, R., \& Batstone, R. (2013). Oral corrective feedback on L2 writing: Two approaches compared, System, 41, 257-268. https://doi.org/10.1016/j.system.2013.03.004

Eslami, E. (2014). The effects of direct and indirect corrective feedback techniques on EFL students' writing. Procedia Social and Behavioral Sciences, 98, 445-452. https://doi.org/10.1016/j.sbspro.2014.03.438

Farrokhi, F., \& Sattarpour, S. (2011). The effects of focused and unfocused written corrective feedback on grammatical accuracy of Iranian EFL learners. Theory and Practice in Language Studies, 1(12), 1797-1803. https://doi.org/10.4304/tpls.1.12.1797-1803

Farrokhi, F., \& Sattarpour, S. (2012). The effects of direct written corrective feedback on improvement of grammatical accuracy of high-proficient L2 learners. World Journal of Education, 2(2), 49-57. https://doi.org/10.5430/wje.v2n2p49

Ferris, D., \& Robert, B. (2001). Error feedback in L2 writing classes: How explicit does it need to be? Journal of Second Language Writing, 10, 161-184. https://doi.org/10.1016/s1060-3743(01)00039-x

Hamidun, N., Hashim, S. H., \& Othman, N. F. (2012). Enhancing students' motivation by providing feedback on writing: The case of international students from Thailand, International Journal of Social Sciecne and Humanity, 2(6), 591-594.

Hosseiny, M. (2014). The role of direct and indirect written corrective feedback in improving Iranian EFL students' writing skill. Procedia Social and Behavioral Sciences, 98, 668-674. https://doi.org/10.1016/j.sbspro.2014.03.466 
Huang, S. J. (2006). A case study of EFL students' writing errors on a web-based writing program. Paper presented at International Conference \& Workshop on TEFL and Applied Linguistics, Ming Chuan University, China.

Hyland, F., \& Hyland, K. (2001). Sugaring the pill: Praise and criticism in written feedback. Journal of Second Language Writing, 10, 185-212. https://doi.org/10.1016/s1060-3743(01)00038-8

Ismail, N., Maulan, S., \& Hasan, N. H. (2008). The impact of teacher feedback on ESL students' writing performance. Academic Journal of Social Sciences, 8(1), 45-54.

Jamalinesari, A., Rahimi, F., Gowhary, H., \& Azizifar, A. (2015). The effect of teacher-written direct vs. indirect feedback on students' writing. Procedia Social and Behavioral Sciences, 192, 116-123. https://doi.org/10.1016/j.sbspro.2015.06.018

Karim, K., \& Nassaji, H. (2013). The role of corrective feedback in second language writing. https://www.tru.ca/shared/assets/Khaled_Karim_and_Hossein_Nassaji-The Role of Corrective feedback in second language writing27031.pdf

Kim, Y. \& Kim, J. (2005). Teaching Korean university writing class: Balancing the process and ther genre approach. Asian EFL Journal, 7(2), 1-15.

Kongsuebchart, J., \& Suppasetseree, S. (2016). A weblog-based electronic portfolio to improve English writing skills of Thai EFL undergraduate students. Paper presented at the Seventh CLS International Conference, National University of Singapore, Singapore.

Lightbown, P. M., \& Spada, N. (1999). How languages are learned. Oxford, UK: Oxford University Press.

Nonkukhetkhong, K. (2013). Grammatical error analysis of the first year English major students, Udon Thani Rajabhat University. Paper presented at the Asian Conference on Language 2013, Osaka, Japan.

Noroozizadeh, S. (2009). Indirect feedback: A plausible suggestion for overcoming error occurrence in L2 writing. The Journal of Asia TEFL, 6(4), 245-262.

Ohta, A. S. (2001). Second language acquisition processes in the classroom: Learning Japanese. Mahwah, $\mathrm{Nj:}$ Lawrence Erlbaum. https://doi.org/10.1017/S0272263101323057

Perez, R. C., Fuentealba, M. M., De La Barra, M. M., Rojas, J. S., \& Cisternas, M. T. (2013). The impact of explicit feedback on EFL high school students engaged in writing tasks. Profile, 15(2), 149-163.

Rattanadilok Na Phuket, P., \& Othman, N. B. (2015). Understanding EFL students' errors in writing. Journal of Education and Practice, 6(32), 99-106.

Razali, R., \& Jupri, R. (2014). Exploring teacher written feedback and student revisions on ESL students' writing. IOSR Journal of Humanities and Social Sciences, 19(5), 63-70. https://doi.org/10.9790/0837-19556370

Sarvestani, M. S., \& Pishkar, K. (2015). The effect of written corrective feedback on writing accuracy of intermediate learners. Theory and Practice in Language Studies, 5(10), 2046-2052. https://doi.org/10.17507/tpls.0510.10

Sermsook, K., Liamnimitr, J., \& Pochakorn, R. (2017). An analysis of errors in written English sentences: A case study of Thai EFL students. English Language Teaching, 10(3), 101-110. https://doi.org/10.5539/elt.v10n3p101

Sheen, Y. (2007). The effect of focused written corrective feedback and language aptitude on ESL learners' $\begin{array}{lllll}\text { acquisition } & \text { of } & \text { aricles. } & \text { 255-283. }\end{array}$ https://doi.org/10.1002/j.1545-7249.2007.tb00059.x

Sheen, Y., Wright, D., \& Moldawa, A. (2009). Differential effects of focused and unfocused written correction on the accurate use of grammatical forms by adult ESL learners. System, 37(4), 556-569. https://doi.org/10.1016/j.system.2009.09.002

Srichanyachon, N. (2012). Teacher written feedback for L2 learners' writing development. Silpakorn University Journal of Social Sciences, Humanities, and Arts, 12(1), 7-17.

Sobhani, M., \& Tayebipour, F. (2015). The effects of oral vs. written corrective feedback on Iranian EFL learners' essay writing. Theory and Practice in Language Studies, 5(8), 1601-1611. https://doi.org/10.17507/tpls.0508.09

Tootkaboni, A. A., \& Khatib, M. (2014). The efficacy of various kinds of error feedback on improving accuracy of EFL learners. Bellaterra Journal of Teaching and Learning Language and Literature, 7(3), 30-46. 
Truscott, J. (1996). The case against grammar correction in L2 writing classes. Language Learning, 46, 327-369. https://doi.org/10.1111/j.1467-1770.1996.tb01238.x

Westmacott, A. (2017). Direct vs. indirect written corrective feedback: Student perceptions. Medellin, 22(1), 17-32.

William, J. G. (2003). Providing feedback on ESL students' written assignments. The Internet TESL Journal, 9(10). http://iteslj.org/Techniques/Williams-Feedback.html.

Zafar, A. (2016). Error analysis: A tool to improve English skills of undergraduate students. Procedia-Social and Behavioral Science, 217, 697-705. https://doi.org/10.1016/j.sbspro.2016.02.122

Zheng, C., \& Park, T. (2013). An analysis of errors in English writing made by Chinese and Korean university students. Theory and Practice in Language Studies, 3(8), 1342-1351. https://doi.org/10.4304/tpls.3.8.1342-1351

\section{Copyrights}

Copyright for this article is retained by the author(s), with first publication rights granted to the journal.

This is an open-access article distributed under the terms and conditions of the Creative Commons Attribution license (http://creativecommons.org/licenses/by/4.0/). 